\title{
OPTIMIZATION OF THE TARIFF ON AUTOMOBILE PASSENGER TRANSPORTATION TO SUBURBAN UNITED
}

\section{Liubov Kytskai}

Ternopil Ivan Pul'uj National Technical University

2, Tantsorova str., 46001, Ternopil, Ukraine

e-mail: lyuba.kytskay@gmail.com

Ph.D., Master's degree of the Department of Economic Cybernetics

OPEN $\bigcirc$ ACCESS

\section{Article history:}

Received: January, 2019

1st Revision: February, 2019

Accepted: March, 2019

\section{JEL classification: R48}

\section{UDC:}

656.032 .23
Abstract. The article deals with problems of transportation of passengers by motor transport in suburban connections in Ukraine. The essence and role of legislative and normative documents of Ukraine in the field of passenger transportation are revealed. The main factors influencing the pricing process in road transport are analyzed, in particular, the justification of the value of passenger transportation tariffs. The role of the state in the regulation of the cost of passenger transportation services is shown and the conditions of their organization are considered. Based on the analysis of the results of inspections of state authorities, it was established that in Ukraine "free" tariffs for passenger transportation services are formed, which enables business entities to regulate prices for this kind of services. Practical calculations have shown that the planned cost of services is one of the most important indicators that affects the pricing of passenger fares in road transport. The mechanism of determining the economically justified tariff for bus travel in suburban traffic has been improved in order to optimize the pricing process in the transport service system. The proposed methodology for determining tariffs for the transportation of passengers in suburban traffic has been proven in the practice of business entities in the Ternopil region.

Keywords: automobile passenger transportation, tariff, passenger, cost, Ukraine.

Kytskai, L. Optimization of the tariff on automobile passenger transportation to suburban united [Електронний ресурс] / Liubov Kytskai // Соціально-економічні проблеми і держава. 2019. - Вип. 1 (20). - С. 3-13. - Режим доступу до журн.: http://sepd.tntu.edu.ua/images/stories/pdf/2019/19klitsu.pdf 


\section{Statement of the problem.}

Motor transport is the main sector of the economy of Ukraine, which provides the needs of the population of domestic passenger transportation by road transport vehicles. Bus passenger transportation as a type of economic activity of business entities should be regulated by the state and self-government bodies, in particular, the establishment of tariffs for the carriage of passengers. Thus, European integration and increased competition in the market of transport services, require new approaches to the creation of new trucking technologies, price formation and quality of services.

\section{Analysis of recent research and publications.}

The analysis of the legislative and regulatory framework showed that the legal regulation of passenger transport operations is carried out in accordance to the current requirements ${ }^{1}$. On the basis of normative documents it is possible to determine the amount of expenses for a certain amount of passenger transportation and the level of the tariff, which must cover it ${ }^{2}$.

Actual problems of domestic automobile passenger transportation, as well as application of different approaches to tariff formation, were studied by such scientists as Yu. S. Barash, V. S. Marunych, K. M. Scherpa, M. D. Shvets, V. N. Zorina and others.

\section{Unsolved aspects of the problem.}

Carrying business in the field of road transport and state regulation creates a number of contradictions regarding the establishment of tariffs for the transportation of passengers and the application of effective methods for their calculation. In addition, authorities and carriers can not solve these issues jointly for a long time, perhaps due to inadequate or insufficient information provision in the process of determining the cost of transportation and is the actual problem nowadays.

\section{Task formulation.}

The purpose of the article is to analyze the legislative and regulatory framework in the field of road transport; the economic justification for calculating the tariff for the carriage of passengers, which serve as the basis for determining the cost of the fare on suburban bus routes.

\section{Main material exposition.}

One of the main functions of motor transport is the provision of services for the transportation of passengers in suburban traffic, bringing profits to both legal and natural persons, but at the same time, it requires considerable expenses. The size of profits in the economic activity of business entities depends on the volume of transportation, as well as tariffs, the size of which is determined on the basis of the cost, which is directly related to the technology of transportation. The solution of tasks for the organization of route bus services in suburban traffic is an urgent problem for all regions of the transport system of Ukraine.

In accordance with Article 1 of the Law of Ukraine "On Road Transport", suburban transportation is the carriage of passengers and baggage in suburban areas, where suburban rates apply and the length of the route does not exceed 50 kilometers $^{3}$. This kind of transportation ensures the regular delivery of the suburban population to the city and in the

\footnotetext{
${ }^{1}$ Pro mistseve samovriaduvannia v Ukraini. No. 24. (1997). Available at: http://zakon0.rada.gov.ua/laws/show/280/97-0D0\%B2\%D1\%80

2 Pro tsiny i tsinoutvorennia. No. 19-20. (2013). Available at: http://zakon0.rada.gov.ua/laws/show/5007-17

${ }^{3}$ Pro avtomobilnyi transport. No. 22. (2001). Available at: http://zakon3.rada.gov.ua/laws/show/2344-14
} 
opposite direction, as well as - urban population to suburban areas and back in order to achieve the labor and cultural and domestic goals of citizens. On the basis of the analysis of the conducted researches it was established that when choosing a type of transport for the population, the price of the ticket, convenience, reliability and regularity of transportation is of great importance.

The rolling stock of some automobile companies or business entities used for bus transportation of passengers must comply with the requirements of the normative documents of Ukraine and the European Union regarding active, passive and environmental safety, as well as certification of the type of vehicle or equipment whose construction complies with the requirements of uniform technical regulations. The roadworthiness certificate is issued by bodies accredited and notified by the United Nations in accordance with the Agreement on the adoption of uniform technical prescriptions for wheeled vehicles ${ }^{4}$. The roadworthiness certificate is issued by bodies accredited and notified by the United Nations in accordance with the Agreement on the adoption of uniform technical prescriptions for wheeled vehicles ${ }^{5}$. The documentation accompanying the certificate of conformity (information package, test results, etc.) presents the complete technical characteristics of motor vehicles, in particular, the fuel consumption rate, passenger capacity, which are important indicators when calculating the tariff for the carriage of passengers by bus.

An important problem of passenger transportation in suburban areas is the formation of tariff policy that should satisfy the entrepreneurial interest, to ensure the development of motor transport, as well as contribute to solving the following main tasks:

- attracting investments in the development of road transport;

- ensuring the competitiveness of entrepreneurs in the market of services;

- ensuring the transparency and predictability of tariffs.

The main factors influencing the pricing process, in particular, the justification of the tariff are: demand, price policy of the state, life cycle of auto transportation services, model of the market, behavior of competitors and consumers, costs, methods of calculating prices, marketing activities of business entities, and others. It should be noted that prices should be determined on the basis of costs, cost of service, overhead costs and profits, which are the ultimate goal of the implementation of tariff policy.

State regulation of prices and control in the field of motor transport in Ukraine is realized through the implementation of economic, tariff, scientific and technical and social policy, licensing, standardization and certification in the motor transport by central and local executive authorities, local self-government bodies. In 2015, the Cabinet of Ministers of Ukraine abolished state and municipal regulation of tariffs for passenger transportation (except for railways), according to which the provision that the bodies of state executive and executive bodies of the city council set tariffs for the carriage of passengers and luggage by buses operating in suburban traffic. From 2015, the Ministry of Infrastructure of Ukraine has introduced a moratorium on tariff regulation for suburban transportation by regional state administrations and city councils. At the same time, it was noted that the ministry does not consider the possibility of a complete abolition of control over pricing in the field of passenger transportation.

The increase of tariffs for the carriage of passengers by road on suburban routes in 2017 was based on the decision of the Antimonopoly Committee and the legislative and regulatory framework of Ukraine ${ }^{6}$. It has been determined that the authority of the executive bodies of village, settlement and city councils includes the authority to establish, in

\footnotetext{
${ }^{4}$ Postanova Kabinetu Ministriv Ukrainy Deiaki pytannia sertyfikatsii transportnykh zasobiv, yikh chastyn ta obladnannia. No. 738. (2011). Available at: http://zakon3.rada.gov.ua/laws/show/738-2011-\%D0\%BF

${ }^{5}$ Nakaz Ministerstva Infrastruktury Ukrainy Pro zatverdzhennia Poriadku zatverdzhennia konstruktsii transportnykh zasobiv, yikh chastyn ta obladnannia ta Poriadku vedennia reiestru sertyfikativ typu transportnykh zasobiv ta obladnannia i vydanykh vyrobnykamy sertyfikativ vidpovidnosti transportnykh zasobiv abo obladnannia. № 521. (2012). Available at: http://zakon2.rada.gov.ua/laws/show/z1586-12

${ }^{6}$ Antymonopolnyi Komitet Ukrainy, Shchodo pidvyshchennia taryfiv na perevezennia pasazhyriv. (2017). Available at:

https://www.kmu.gov.ua/ua/news/249669757
} 
accordance with the procedure and within the limits defined by the legislation, in particular, tariffs for transport services. Regional state administrations and local self-government bodies take responsibility for the formation of a network of public bus routes in suburban areas in the usual mode, as well as control the observance of legislation in the field of motor transport in the certain territory. One of the essential and inalienable conditions of the contract is the price (fare), which is set by the carriers. Consequently, the formation of the price of services for the carriage of passengers by road, which do the routes on the territories of the regions of Ukraine, is based on contractual relationships between motor carriers, regional and district state administrations and local self-government bodies. However, some state authorities refrain from exercising their power of carrying out tariff policy on motor transport, referring to the removal from the annex to the resolution of the Cabinet of Ministers of Ukraine of a paragraph on the establishment by regional state administrations of tariffs for the carriage of passengers and luggage by buses operating in suburban traffic that is violation of the legislation on the protection of economic competition.

An analysis of the activities of state authorities in 2017 showed that the Antimonopoly Committee of Ukraine studied the situation that arose from the self-annulment of the relevant state bodies of certain regions of Ukraine regarding the control of tariffs for the carriage of passengers by public transport on suburban bus routes. According to the results of inspections, it was established that the violation by certain state bodies of the current legislation in the field of motor transport and protection of economic competition, as well as the procedure for organizing road transport of passengers on suburban routes ${ }^{7}$. In order to prevent violations of the legislation on the protection of economic competition, the Antimonopoly Committee of Ukraine provided local authorities with a number of recommendations for consideration, in particular: to ensure the verification of already concluded contracts for the carriage of passengers by road on suburban routes; to check the presence of such conditions of organization of transportation as tariffs and the order of their change, and in the absence of such conditions - to initiate the introduction of appropriate changes to the agreements concluded with carriers; to ensure the competitive selection of carriers taking into account the cost of their services. This is a confirmation of the fact that the formation of prices (tariffs) for bus transport of passengers is an obligatory document during the competitive selection of carriers; in case of increase by carriers the tariffs for the carriage of passengers on bus routes operating in the usual mode of movement and is an integral part of the passport of the route.

An analysis of literary sources has shown that specialists offer the possibility of using variable pricing, which can be used in the case of increased cost of fuel and lubricants and costs. Transportation of passengers in suburban buses from 2015 is carried out at the tariff which is set by the carriers themselves and represents the cost of passenger transportation per kilometer. Consequently, the level of the tariff depends to a large extent on the cost of transportation. Nowadays, state regulation of the cost of services for the carriage of passengers in suburban traffic has been canceled, and carriers, got the right to establish "free tariffs" themselves with the consent of the parties. However, the self-annulment of state regulation of tariffs for passenger services did not deprive the relevant state bodies of control functions regarding pricing issues for these services and did not abolish the need to ensure the validity of such tariffs.

The economic situation in Ukraine has led to a significant increase in prices for a number of articles of costing costs, production cost of services, in particular, the growth of the minimum wage, the cost of fuel and lubricants. Due to the unprofitableness of road haulage, carriers can not ensure the proper quality of the technical condition of buses, follow to the

\footnotetext{
7 Rekomendatsii Antymonopolnoho Komitetu Ukrainy Pro zapobihannia porushenniam zakonodavstva pro zakhyst ekonomichnoi konkurentsii. No. 10-rk. (2017). Available at: http://document.ua/pro-zapobigannja-porushennjam-zakonodavstva-pro-zahist-ekonodoc308720.html
} 
schedules of traffic on routes and ensure the safety of traffic, which in the future can lead to emergency situations and traffic accidents. This problem applies, in particular, to suburban car connections and affects all members of the territorial community that use this type of service, and also affects the business entities that carry out passenger transportation.

The article considers the peculiarities of the formation of "free tariffs" for the services of passenger motor transport in suburban traffic. The revision of the tariff level is related to changes in the conditions of production activity and the implementation of services that are independent of the carrier's economic activities, including in the event of a change in the cost of fuel by more than $10 \%$.

Due to the increase in the minimum wage, direct labor costs, taxes, and the minimum insurance contribution paid by the carrier in accordance with the requirements of the current legislation have increased. All these and other expenses directly affect the formation of the cost of the fare for commuting.

According to the "Methodology for calculation of tariffs for passenger motor transport services", the calculation of tariffs for passenger transportation includes:

- $\quad$ the cost of wages of drivers of vehicles used for hiring;

- the planning and calculation of the costs of the carrier are carried out on the basis of the regulatory method, taking into account the sectoral norms of use of material and fuel and energy resources;

- $\quad$ projected cost planning, based on the actual previous year;

- charging of depreciation of fixed assets, other non-negotiable material and intangible assets of the carrier, taking into account the expected method of obtaining economic benefits from its use;

- $\quad$ vehicles received under leasing agreements (leases);

- $\quad$ costs according to loan agreements; tax rates and fees;

- the total amount of transport work and the total number of passengers carried, including those taking into account the privileged categories of passengers who, in accordance with the legislation, have such rights.

Calculation of tariffs for automobile passenger transportation, provided on suburban bus routes, is carried out in accordance with calculated planned cost of services with the use of the necessary profit for operation and development of the carrier. The planned cost includes planning the costs of entrepreneurs-carriers, which is carried out taking into account the costs of operating activities and financial costs associated with the carriage of passengers and baggage. It is expedient to include planned profit in calculating the tariff for the purpose of developing a carrier's business, calculated as a percentage of the production cost.

By 2017, the State Budget of Ukraine for compensation for carriers' entrepreneurs for privileged passage of certain categories of citizens defined by the legislation were provided. The Law of Ukraine "About the State Budget of Ukraine for 2017" does not provide for such expenditures. According to Article 91 of the Budget Code of Ukraine, expenditures of local budgets may be made from all local budgets, in particular: compensatory payments for privileged travel of certain categories of citizens; regulation of prices (tariffs) for the carriage of passengers in passenger transport by a decision of the local executive body and local selfgovernment body in accordance with the given powers. Such innovations concerning the regulation of the main issues of automobile passenger transport in all regions of Ukraine will allow to pay more attention to the development of transport infrastructure and tariff regulation for the carriage of passengers in suburban traffic. Due to this, territorial communities of Ukraine should accept local budgets each year, which should reflect the above-mentioned expenses and this is evidence of the fact that it will increase the burden on local budgets.

Taking into account the foregoing, as well as changing the conditions of production activity and the implementation of services that do not depend on the economic activity of 
carriers, there was a need to revise the tariff for the carriage of passengers in suburban traffic. This will enable economic entities to carry out transport services without loss.

The carriers participating in the route tender submit a reasonable calculation of the tariff for the carriage of passengers. Such calculations should be submitted in the case of receipts of citizens' appeals to the Regional State Administration on the carrier regarding violations of the conditions of transportation and inconsistency of actual costs (at the time of appeal) to the level of costs imposed on the current tariff for the provision of services for the transportation of passengers on bus routes.

In order to optimize the pricing process in the system of transport services, it is advisable to propose the following mechanism for calculating of the passenger fare for suburban car connections:

1. To determine the tariff, it is necessary to take into account the producer price index. This will allow you to index the cost of fuel and lubricants, tools, spare parts, aggregates, devices, repair materials, automotive tires and batteries.

2. Expenses for the payment of drivers (in accordance with the requirements of the current legislation, the terms of the employment contract, taking into account the minimum wage and the average wage for the current year, the number of drivers, the driver's tariff rate, the number of worked months in the current year).

3. Define vehicle run for 1 year and 1 month:

$$
L=L_{r} \times Z_{r} \times D,
$$

where, $L$ - mileage of a passenger vehicle for 1 year, $\mathrm{km}$;

$L_{r}$ - the length of the route in the forward and reverse directions, km;

$Z_{r}$ - number of routes for 1 day;

$D$ - number of working days in 1 year, days.

$$
L m=\frac{L}{N^{\prime}}
$$

where, $L_{m}$ - mileage of a passenger vehicle for 1 month, $\mathrm{km}$;

$L$ - mileage of a passenger vehicle for 1 year, $\mathrm{km}$;

$N$ - number of months of operation of the bus on the route.

4. Calculation of fuel costs per kilometer of the vehicle. Fuel costs for vehicles are referred to both to the direct material costs and to the scheduled costs of the carrier. Determining the rate of fuel consumption $100 \mathrm{~km}$ vehicle designed for planning of fuel and lubricants and monitor their costs of reporting, the introduction of austerity and rational use of oil and can be used to develop specific rate of fuel consumption. Calculation of fuel consumption for $1 \mathrm{~km}$ of bus run on the route is calculated by the formula:

$$
W_{f 1 k m}=0,01 \times N_{f} \times(1+0,01 \times \mathrm{Ks}) \times P_{f}, \mathrm{UAH} / \mathrm{km}
$$

where, $N_{f}$ - base linear fuel consumption rate for a specific brand of motor vehicle, l/100 km (cub.m/100 km);

$K_{s}$ - the total corrective factor of the basic linear norm, which takes into account the specific conditions of operation of the bus;

$\mathrm{s}$ - amount sign;

$P_{f}$ - estimated fuel price, $\mathrm{UAH} / \mathrm{L}\left(\mathrm{UAH} / \mathrm{m}^{3}\right)$.

Formula (3) is used to calculate fuel consumption for bus operation for normal operation during passenger transportation on suburban routes. As it was noted, fuel consumption rates for a particular vehicle increase depending on the conditions of its 
operation. In particular, fuel consumption rates increase in case of cold weather, depending on the actual ambient air temperature, which is an important factor in calculating fuel costs per $1 \mathrm{~km}$ of bus run: from $0{ }^{\circ} \mathrm{C}$ (inclusive) to $-5^{\circ} \mathrm{C}$ inclusive - up to $2 \%$; below $-5{ }^{\circ} \mathrm{C}$ and up to $10{ }^{\circ} \mathrm{C}$ inclusive - up to $4 \%$; below $-10{ }^{\circ} \mathrm{C}$ and up to $-15{ }^{\circ} \mathrm{C}$ inclusive - up to $6 \%$; below $-15{ }^{\circ} \mathrm{C}$ and up to $-20{ }^{\circ} \mathrm{C}$ inclusive - up to $8 \%$; below $-20{ }^{\circ} \mathrm{C}$ and up to $-25{ }^{\circ} \mathrm{C}$ inclusive - up to $10 \%$; below $-25{ }^{\circ} \mathrm{C}$ - up to $12 \%$.

Based on the results of calculations, we determine the costs of the carrier for fuel per year mileage of the bus:

$$
W_{f}=W_{f 1 k m} \times \mathrm{L}_{f}
$$

5. The cost of lubricants per kilometer of the vehicle. The cost of lubricants is calculated on the basis of the cost formula per kilometer of the vehicle in proportion to the fuel consumption with the use of linear (temporary - in the absence of linear) standards for the consumption of lubricants in road transport ${ }^{8}$ :

$$
W_{l 1 k m}=0,01 \times \mathrm{W}_{f}^{\prime} \times\left(\mathrm{N}_{\mathrm{M}} \times P_{\mathrm{M}}+\mathrm{N}_{\mathrm{tr}} \times P_{\mathrm{tr}}+\mathrm{N}_{s p} \times P_{\mathrm{sp}}+\mathrm{N}_{\mathrm{pk}} \times P_{\mathrm{pl}}\right), \mathrm{UAH} / \mathrm{km}
$$

where, $W_{l 1 \mathrm{~km}}$ - the cost of lubricants per kilometer of the vehicle;

$$
\begin{gathered}
\mathrm{N}_{\mathrm{M}}, \mathrm{N}_{t r}, \mathrm{~N}_{s p}, \mathrm{~N}_{\mathrm{pl}}-\text { consumption rates for motor, transmission, special oils }(\mathrm{l} / 100 \mathrm{l} \text { of } \\
\text { fuel) and plastic oils (kg/100 l of fuel); } \\
\mathrm{P}_{\mathrm{M}}, P_{t r}, P_{\mathrm{sp}}, \mathrm{P}_{\mathrm{pl}} \text { - the projected price for motor, transmission, special oils (UAH/l) and } \\
\text { plastic oils (UAH/kg), respectively. }
\end{gathered}
$$

Based on the results of calculations, we determine the costs of the carrier for lubricants on the annual mileage of the bus:

$$
W_{f}=W_{f 1 k m} \times \mathrm{L}, \mathrm{UAH}
$$

6. Costs for car tires at $1 \mathrm{~km}$ run. For calculations take into account the model (modification) of the bus, which carries passengers on a specific route, brands of automobile tires. The cost of an automobile bus for $1 \mathrm{~km}$ of motor vehicle run is determined by the formula:

$$
W=\frac{P \times N_{t}}{N \times \mathrm{K}_{c}}, \mathrm{UAH} / \mathrm{km},
$$

where, $P$ - estimated price of automobile tires, UAH;

$\mathrm{N}_{\mathrm{t}}$ - number of tires installed on a single motor vehicle, units;

$N$ - operating rate of average tire resource, km;

$K_{c}-$ an adjustment factor that takes into account the operating conditions.

Determine the cost of car tires for 1 year of bus run:

$$
W_{t}=W_{t 1 k m} \times L, \mathrm{UAH}
$$

7. The expenses on the batteries $(\mathrm{AB})$ are calculated on the basis of expenses for $1 \mathrm{~km}$ run of the bus:

\footnotetext{
8 Lyst Pro zatverdzhennia Norm vytrat palyva i mastylnykh materialiv na avtomobilnomu transporti. No. 4. (1998). Available at: http://consultant.parus.ua/?doc=0A7NKC2767
} 


$$
W_{A B 1 \mathrm{~km}}=\frac{P_{A B} \times N_{A B}}{N_{s t} \times \mathrm{K}_{k} \times \mathrm{I}}, \mathrm{UAH} / \mathrm{km}
$$

where, $P_{A B}$ - the forecasted price of AB, $\mathrm{UAH}$;

$N_{A B}$ - number of units installed on one bus;

$N_{s t}$ - operating standard of average resource AB, months;

$K_{k}-$ adjustment factor that takes into account the operating conditions (GOST 2162481);

I - actual intensity of bus operation, $\mathrm{km} /$ month.

Consequently, in order to calculate the annual costs of accumulator batteries, they take into account their number on the vehicle, the cost, work life, norms of the average resource of the $\mathrm{AB}$ in calendar months and the correction factors, depending on the conditions of operation of the bus.

8. Expenses on materials and spare parts by types of maintenance, for the repairing of buses used for the carriage of passengers in suburban traffic are determined on the basis of the cost of materials and spare parts per kilometer of the motor vehicle. Annual number of technical impacts $\left(\mathrm{N}_{\mathrm{r}}\right)$ for each bus model:

$$
N_{r}=\frac{L_{r}}{L_{k}}
$$

where, $L_{r}$ - annual mileage of the bus, km;

$L_{k}-$ adjusted mileage to major repairs, $\mathrm{km}$.

Annual expenses for maintenance and repair of the bus depending on its run:

$$
W=W_{m r} \times L, \mathrm{UAH}
$$

It should be noted that the annual total cost of buses used for the carriage of passengers include maintenance and repair costs, as well as the cost of purchasing spare parts, materials and their replacement during maintenance and current bus repair.

9. Depreciation costs is a systematic allocation of the cost of fixed assets, other noncurrent and intangible assets that are depreciated over their useful life (exploitation). The amount of depreciation in accounting may affect the cost of services for passenger transportation, the amount during the reporting period, as well as the financial result of the reporting period. The minimum allowable depreciation period for fixed assets and other noncurrent assets is established in subparagraph 138.3 .3 of paragraph 138.3 of Article 138 of the Tax Code of Ukraine, in particular, vehicles are classified in group 5 (useful life of them is 5 years). Article 145 of the Tax Code provides for five basic methods of depreciation of fixed assets ${ }^{9}$.

10. Other direct expenses, which can be attributed to expenses:

- for performance of drivers for the current year (according to the contract);

- for obligatory insurance of civil liability of owners of vehicles;

- for compulsory personal insurance of drivers from accidents in transport;

- for pre-tour medical examination of drivers of vehicles;

- costs for pre-departure maintenance and parking place for the bus; single tax.

11. Planned cost of service is defined as the sum of all costs specified in items 1-10.

12. Determination of the tariff for the carriage of passengers by suburban bus. Profitability Indicator, which takes into account profits and costs, gives you the most accurate

\footnotetext{
Podatkovyi Kodeks Ukrainy. No. 13-17. 2011.

Available at:

http://zakon2.rada.gov.ua/laws/show/2755- 
way to determine how profitable your business is. Profitability is a relative indicator of any type of business. The profitability is influenced by various factors: sources of capital, asset value, working capital, cash, and other. With this ratio you can estimate the future profit from the services planned for implementation at the enterprise.

On the routes serviced by suburban transport, „free“ pricing is applied. Tariffs for carriage of passengers shall provide the carrier with: compensation for reasonable current expenses; renewal of rolling stock in the amount of $8-12 \%$ per year; providing investment attractiveness for the profitability of transportation - 10-15\%.

Thus, for calculating the tariff for services for the carriage of passengers in a suburban bus route, determine:

- planned annual profit from the provision of services;

- survey of passenger traffic for the year;

- scheduled annual transport work on the route (justified by the carrier on the basis of actual performance or established on the basis of the survey of passenger traffic);

- planned annual cost of services.

The tariff for services for the carriage of passengers in a suburban route is determined by:

$$
T_{s t}=\frac{s+P}{W_{t}}, \mathrm{UAH} / \mathrm{pkm}
$$

where, $T_{s t}$ - tariffs for services for passenger transportation on suburban bus routes of general use, $\mathrm{UAH} / \mathrm{pkm}$;

$S$ - planned annual cost of services, UAH;

$P$ - planned annual profit from the provision of services, UAH;

$W_{t}-$ scheduled annual transport work on the route, $\mathrm{pkm}$.

After the calculations, the fare is agreed with the bus stations. It should be noted that the tariffs for services are determined without taking into account the charge for mandatory services rendered by bus stations to passengers. On the basis of the fare, carriers and bus stations calculate their own income and reflect them in their accounting and reporting. Tariff charges for suburban routes are established by multiplying the kilometer distance from the beginning of the route to the middle of the tariff zone and adding value added tax and insurance payment.

\section{Conclusions.}

Thus, the analysis of the current legislative and regulatory framework in the field of road transport of passengers made possible to optimize the method of calculating the planned cost of service and to determine the tariff for passenger transportation. The economically justified calculation of the tariff for passenger transportation is the main document on the basis of which the full cost of the ticket for passenger transportation on the corresponding route in a suburban connection is calculated. This technique includes the elements necessary to determine the tariff for transportation, and can be applied to any road transport of passenger traffic.

The main promising areas of scientific research are the analysis of the normative basis of motor transport and the improvement of the methodology for calculating the cost of services and the tariff for the carriage of passengers in urban transport and international traffic. Correct organization of work of motor transport will allow: to increase the quality of life at the local and regional level; promote the development of passenger transport infrastructure; preventing unwarranted increase of tariffs; improve the level of servicing of passengers, financial status of economic entities and controllability of the price situation in the passenger transport market. 


\title{
Author details (in Russian) ОПТИМИЗАЦИЯ ТАРИФА НА АВТОПЕРЕВОЗКИ ПАССАЖИРОВ В ПРИГОРОДНОМ СООБЩЕНИИ
}

Любовь Кицкай

\author{
Тернопольский национальный технический университет имени Ивана Пулюя \\ ул. Танцорова, 2, г. Тернополь, 46001, Украина \\ e-mail: lyuba.kytskay@gmail.com \\ к.т.н., магистр кафедры экономической кибернетики
}

Аннотация. $B$ статье рассматриваются проблемы перевозок пассажиров автомобильным транспортом в пригородном сообщении в Украине. Раскрыта сущность и роль законодательных и нормативных документов Украины в области пассажирских перевозок. Проанализированы основные факторы, влияющие на процесс ценообразования на автомобильном транспорте, в частности обоснование величины тарифов перевозки пассажиров. Показана роль государства в регулировании стоимости услуг автоперевозок пассажиров и рассмотрены условия их организации. На основании анализа результатов проверок государственных органов, установлено, что в Украине формируются "свободные" тарифы на услуги по перевозке пассажиров, что позволяет субъектам предпринимательской деятельности регулировать цены на такой вид услуг. Практические расчёты показали, что плановая себестоимость услуг является одним из важнейших показателей, который влияет на определение цены проезда пассажиров в автомобильном транспорте. Усовершенствован механизм определения экономически обоснованного тариба на проезд в автобусе в пригородном сообщении с целью оптимизации процесса ценообразования в системе транспортного обслуживания. Предложенная методика определения тарифов на перевозки пассажиров в пригородном сообщении апробирована в практической деятельности субъектов предпринимательства в Тернопольской области.

Ключевые слова: автомобильные пассажирские перевозки, тариф, пассажир, цена, Украина.

\section{Author details (in Ukrainian) \\ ОПТИМІЗАЦІЯ ТАРИФУ НА АВТОМОБІЛЬНІ ПЕРЕВЕЗЕННЯ ПАСАЖИРІВ У ПРИМІСЬКОМУ СПОЛУЧЕННІ}

Любов Кицкай

Тернопільський національний технічний університет імені Івана Пулюя

вул. Танцорова, 2, м. Тернопіль, 46001, Україна

e-mail: lyuba.kytskay@gmail.com

к.т.н., магістр кафедри економічної кібернетики

Анотація. $\quad$ с статті розглядаються проблеми перевезень пасажирів автомобільним транспортом у приміських сполученнях в Україні. Розкрито сутність $i$ роль законодавчих та нормативних документів України в галузі пасажирських перевезень. Проаналізовано основні чинники, які впливають на процес ціноутворення на автомобільному транспорті, зокрема обгрунтування величини тарифів перевезення пасажирів. Показана роль держави в регулюванні вартості послуг автоперевезень пасажирів та розглянуто умови їх організації. На підставі аналізу результатів перевірок державних органів, встановлено, що в Україні формуються "вільні" тарифи на послуги з перевезення пасажирів, що дає змогу суб'єктам підприємнищької діяльності регулювати ціни на такий вид послуг. Практичні розрахунки показали, що планова собівартість послуг є одним із найважливіших показників, який впливає на визначення ціни проїзду пасажирів в автомобільному транспорті. Удосконалено механізм визначення економічно обгрунтованого тарифу на проїзд в автобусі у приміському сполученні з метою оптимізації процесу ціноутворення в системі транспортного обслуговування. Запропонована методика визначення тарифів на перевезення пасажирів у приміському сполученні апробована в практичній діяльності суб'єктів 
підприємництва в Тернопільській області.

Ключові слова: автомобільні пасажирські перевезення, тариф, пасажир, ціна, Україна.

\section{Appendix A. Supplementary material}

Supplementary data associated with this article can be found, in the online version, at http://sepd.tntu.edu.ua/images/stories/pdf/2019/19klitsu.pdf

\section{Funding}

The authors received no direct funding for this research.

\section{Citation information}

Kytskai, L. (2019) Optimization of the tariff on automobile passenger transportation to suburban united. Sotsialnoekonomichni problemy i derzhava [Socio-Economic Problems and the State] (electronic journal), Vol. 20, no. 1, pp. 313. Available at: http://sepd.tntu.edu.ua/images/stories/pdf/2019/19klitsu.pdf

\section{References}

1. Budget Code of Ukraine. No. 50-51. (2010). Retrieved from http://zakon3.rada.gov.ua/laws/show/2456-17

2. Marunych, V.S. (2017) Orhanizatsiia ta upravlinnia pasazhyrskymy perevezenniamy [Organization and management of passenger transportation]. Kyiv: Milenium. (in Ukrainian)

3. National Institute of Mental Health. (1990). Clinical training in serious mental illness (DHHS Publication No. ADM 90-1679). Washington, DC: U.S. Government Printing Office.

4. Pro Derzhavnyi biudzhet Ukrainy na 2017 rik. No. 3. (2017). Retrieved from http://zakon2.rada.gov.ua/laws/show/1801-19

5. Pro vstanovlennia povnovazhen orhaniv vykonavchoi vlady ta vykonavchykh orhaniv miskykh rad shchodo rehuliuvannia tsin (taryfiv). No. 240. (2015). Retrieved from http://zakon5.rada.gov.ua/laws/show/1548-96-\%D0\%BF

6. Pro zakhyst ekonomichnoi konkurentsii. No. 12. (2002). Retrieved from http://zakon0.rada.gov.ua/laws/show/2210-14

7. Sherepa, K. M. (2011) Struktura vytrat u taryfakh na pasazhyrski perevezennia u vnutrishnomu spoluchenni [Cost structure in passenger intercity tariffs]. Zbirnyk naukovykh pracj "Problemy pidvyshhennja efektyvnosti infrastruktury", no. 31. Available at: http://jrnl.nau.edu.ua/index.php/PPEI/article/viewFile/366/355 (accessed 16 January 2019).

8. Shvets, M. D., Turcheniuk, M. O. (2010) Metodyka vyznachennja taryfu ta sobivartosti perevezenj pasazhyriv avtomobiljnym transportom za okremymy stattjamy [Methodology for determining the tariff and cost of transporting passengers by road by individual articles]. Visnyk Natsionalnoho universytetu vodnoho hospodarstva ta pryrodokorystuvannia: Zbirnyk naukovykh prats, Serija: Ekonomika, vol. 4, pp. 236-243.

9. Zorina, V. N., Senina, H. V. (2005) Formuvannia ta kalkuliuvannia sobivartosti produktsii (robit, posluh) $v$ haluziakh narodnoho hospodarstva [Formation and calculation of the cost of products (works, services) in the branches of the national economy]. Kyiv: Tsentr navchalnoi literatury. (in Ukrainian).

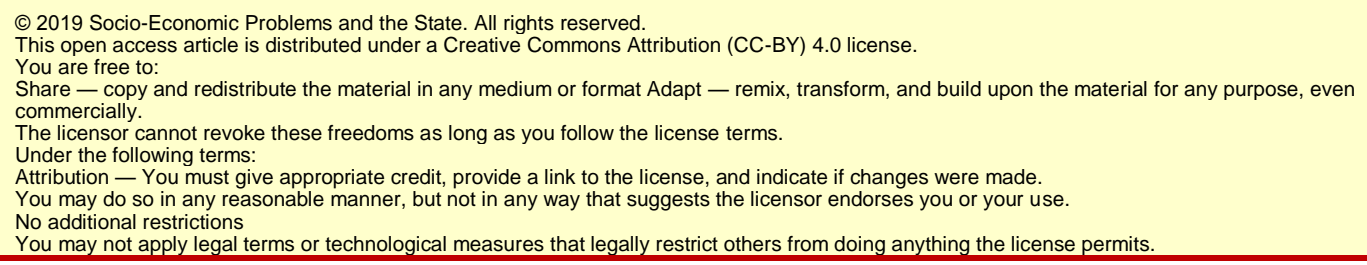

Socio-Economic Problems and the State (ISSN: 2223-3822) is published by Academy of Social Management (ASM) and Ternopil Ivan Pul'uj National Technical University (TNTU), Ukraine, Europe.

Publishing with SEPS ensures:

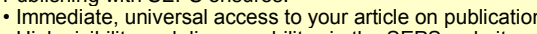

- High visibility and discoverability via the SEPS website

- Rapid publication

- Guaranteed legacy preservation of your article

Submit your manuscript to a SEPS journal at http://sepd.tntu.edu.ua 